\title{
Bilateral High Signal Intensity on DWI of the Precentral Cortices in Mitochondriopathy Due to MTO1 Mutation and MT-TF Variant
}

Guillaume Dorcet,* Vincent Fabry, MD, Fabrice Bonneville, MD, PhD,* and Pascal Cintas, MD

Neurology ${ }^{\circledR}$ 2021;96:288-289. doi:10.1212/WNL.0000000000011374

Figure MRI Presentation of Mitochondriopathy Due to MTO1 Mutation and MT-TFVariant in Adults
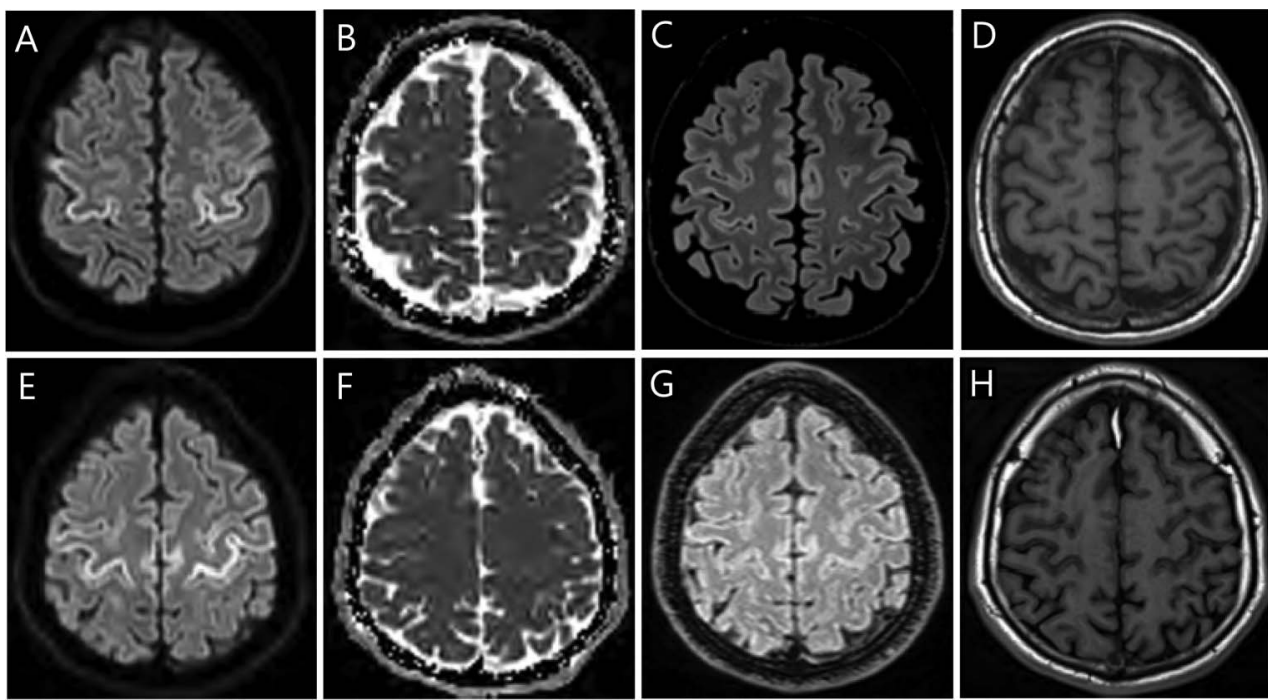

Brain MRIs of a sister (upper line, 39 years old) and her brother (lower line, 37 years old) with MTO1 mutation and MTFT variant showing cortical, bilateral, symmetric, b1000 DWI hypersignal of the precentral gyri (A, E) without ADC restriction (B, F) nor FLAIR (C, G) or T1 abnormality (D, H).

A 40-year-old woman and her 38-year-old brother developed since childhood optic neuropathy, absence epilepsy, cognitive disability, cerebellar syndrome, hypertrophic cardiomyopathy, and scoliokyphosis, due to a mitochondriopathy associating MTO1 mutation and an MT-FT variant, both genes involved in mitochondrial tRNA modification. ${ }^{1}$ Brain MRIs were normal during childhood, but cortical, symmetric hyperintensities of precentral gyri on diffusionweighted imaging (figure) arose apart from any new symptom, different from previously reported MTO1 mitochondriopathies, only noncortical, ${ }^{2}$ from status epilepticus, generally unilateral and associated with a thalamic or corpus callosum splenium hypersignal, and from Creutzfeldt-Jakob disease, usually more posterior and associated with pulvinar and basal ganglia hyperintensities.

\section{Study Funding}

Centre Hospitalier Universitaire de Toulouse.

\author{
Correspondence \\ Mr. Dorcet \\ guillaume.dorcet@ \\ gmail.com
}

*These authors contributed equally to this work.

From the Département de Neurologie (G.D., V.F., P.C.) and Service de Neuroradiologie (F.B.), Hôpital Pierre Paul Riquet, CHU de Toulouse; INSERM U1043-CNRS UMR 5282 (G.D.) Centre de Physiopathologie Toulouse-Purpan; INSERM U1031-CNRS ERL5311 (V.F.), STROMALab, Toulouse; and Université Paul Sabatier-Toulouse III (P.C.), France.

Go to Neurology.org/N for full disclosures. Funding information and disclosures deemed relevant by the authors, if any, are provided at the end of the article. 


\section{Disclosure}

The authors report no disclosures relevant to the manuscript. Go to Neurology.org/ $\mathrm{N}$ for full disclosures.

\section{Appendix Authors}

\begin{tabular}{lll}
\hline Name & Location & Contribution \\
\hline $\begin{array}{l}\text { Guillaume } \\
\text { Dorcet }\end{array}$ & $\begin{array}{l}\text { Département de } \\
\text { Neurologie, Hôpital Pierre } \\
\text { Paul Riquet, CHU de } \\
\text { Toulouse, France }\end{array}$ & $\begin{array}{l}\text { Case report concept, design } \\
\text { and critical revision of } \\
\text { content, and conduct of the } \\
\text { case report }\end{array}$ \\
\hline $\begin{array}{ll}\text { Vincent } \\
\text { Fabry, MD }\end{array}$ & $\begin{array}{l}\text { Département de } \\
\text { Neurologie, Hôpital Pierre } \\
\text { Paul Riquet, CHU de } \\
\text { Toulouse, France }\end{array}$ & \\
& Critical revision of content \\
\end{tabular}

\begin{tabular}{lll} 
Appendix & (continued) & \\
\hline Name & Location & Contribution \\
\hline $\begin{array}{l}\text { Fabrice } \\
\text { Bonneville, } \\
\text { MD, PhD }\end{array}$ & $\begin{array}{l}\text { Service de } \\
\text { Neuroradiologie, Hôpital } \\
\text { Toulouse, France }\end{array}$ & $\begin{array}{l}\text { Case report design, critical } \\
\text { revision of content }\end{array}$ \\
\hline $\begin{array}{l}\text { Pascale } \\
\text { Cintas, MD }\end{array}$ & $\begin{array}{l}\text { Département de } \\
\text { Neurologie, Hôpital Pierre }\end{array}$ & $\begin{array}{l}\text { Major role in the acquisition } \\
\text { of data, case repost } \\
\text { concept, critical revision of } \\
\text { the manuscript content }\end{array}$ \\
& $\begin{array}{l}\text { Toulouse, France } \\
\end{array}$ & \\
\hline
\end{tabular}

\section{References}

1. Charif M, Titah SMC, Roubertie A, et al. Optic neuropathy, cardiomyopathy, cognitive disability in patients with a homozygous mutation in the nuclear MTO1 and a mitochondrial MT-TF variant. Am J Med Genet A 2015;167A:2366-2374.

2. O'Byrne JJ, Tarailo-Graovac M, Ghani A, et al. The genotypic and phenotypic spectrum of MTO1 deficiency. Mol Genet Metab 2018;123:28-42.

\section{COVID-19 and Neurologic Disease: Call for Papers!}

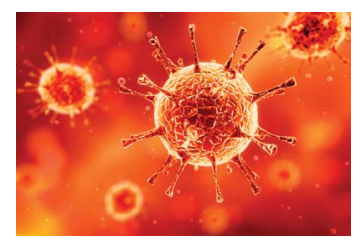

The editors of Neurology are interested in papers that address the neurological aspects of COVID-19 infection and challenges to the management of patients with chronic neurological conditions who have, or are at risk for, the infection. Relevant papers that pass initial internal review will undergo expedited peer review and online publication. We will consider papers posted in preprint servers.

Submit observational studies and clinical trials as Articles and case series and case reports under the Clinical/Scientific Notes category to https://submit.neurology.org/ today!

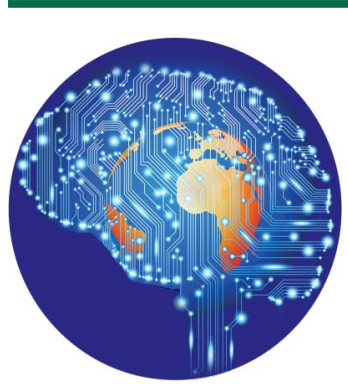

\section{Practice Current: An interactive exchange on controversial topics}

Share your own best practices.

Read commentary with expert opinion.

Explore results on an interactive world map.

NPub.org/NCP/practicecurrent

Neurolog ${ }^{\circledR}$ Clinical Practice 


\section{Neurology}

\section{Bilateral High Signal Intensity on DWI of the Precentral Cortices in Mitochondriopathy Due to MTO1 Mutation and MT-TF Variant \\ Guillaume Dorcet, Vincent Fabry, Fabrice Bonneville, et al.}

Neurology 2021;96;288-289 Published Online before print December 22, 2020

DOI 10.1212/WNL.0000000000011374

This information is current as of December 22, 2020

\section{Updated Information \&} Services

References

Subspecialty Collections

Permissions \& Licensing

Reprints including high resolution figures, can be found at: http://n.neurology.org/content/96/6/288.full

This article cites 2 articles, 0 of which you can access for free at: http://n.neurology.org/content/96/6/288.full\#ref-list-1

This article, along with others on similar topics, appears in the following collection(s):

\section{DWI}

http://n.neurology.org/cgi/collection/dwi

Metabolic disease (inherited)

http://n.neurology.org/cgi/collection/metabolic_disease_inherited Mitochondrial disorders

http://n.neurology.org/cgi/collection/mitochondrial_disorders

Mitochondrial disorders; see Genetics/Mitochondrial disorders http://n.neurology.org/cgi/collection/mitochondrial_disorders_see_gene tics-mitochondrial_disorders

MRI

http://n.neurology.org/cgi/collection/mri

Information about reproducing this article in parts (figures,tables) or in its entirety can be found online at:

http://www.neurology.org/about/about_the_journal\#permissions

Information about ordering reprints can be found online:

http://n.neurology.org/subscribers/advertise

Neurology ${ }^{\circledR}$ is the official journal of the American Academy of Neurology. Published continuously since 1951, it is now a weekly with 48 issues per year. Copyright @ 2020 American Academy of Neurology. All rights reserved. Print ISSN: 0028-3878. Online ISSN: 1526-632X.

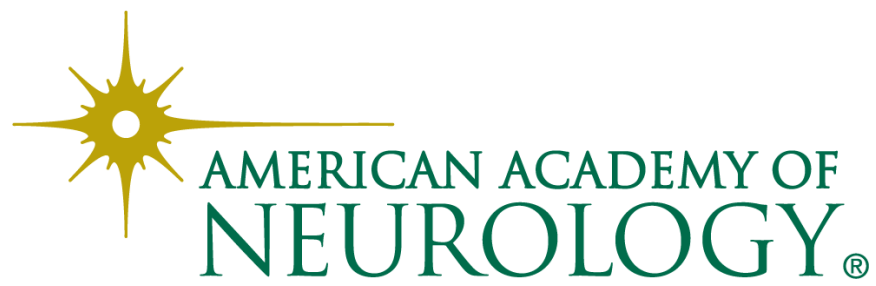

